\title{
Sodium-Dependent Serotonin Transporter
}

National Cancer Institute

\section{Source}

National Cancer Institute. Sodium-Dependent Serotonin Transporter. NCI Thesaurus. Code C105876.

Sodium-dependent serotonin transporter (630 aa, $70 \mathrm{kDa}$ ) is encoded by the human SLC6A4 gene. This protein is involved in serotonin internalization. 